
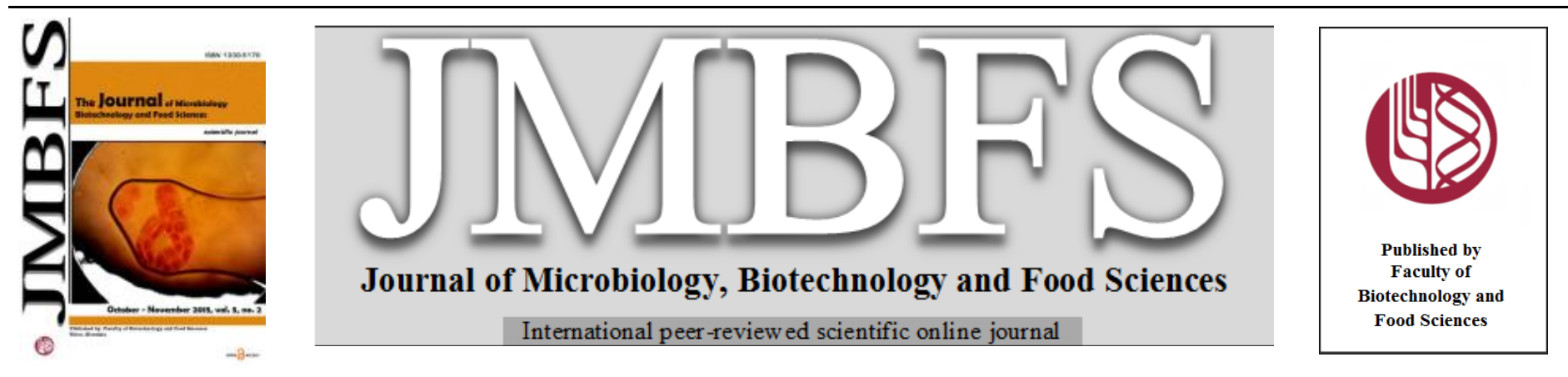

\title{
BRANCHED CHAIN AMINO ACIDS AND THEIR IMPORTANCE IN NUTRITION
}

Matej Brestenskýl ${ }^{1}$, Soňa Nitrayová ${ }^{1}$, Peter Patráś $\check{I}^{1}$, Jaroslav Heger ${ }^{1}$,Jozef Nitray ${ }^{2}$

Address(es): Ing. Matej Brestenský, PhD.

${ }^{l}$ National Agricultural and Food Center, Research Institute of Animal Production Nitra, Institute of Nutrition, Hlohovecká 2, 95141 Lužianky, Slovakia, +4216546 182.

${ }^{2}$ Tekmar Slovakia Co. Ltd., Vinárska 26, 95141 Lužianky, Slovakia.

*Corresponding author: $\underline{m} \_$brestensky@ vuzv.sk

doi: 10.15414/jmbfs.2015.5.2.197-202

\section{ARTICLE INFO}

Received 24. 3. 2015

Revised 13. 7. 2015

Accepted 17. 8. 2015

Published 1. 10. 2015

Review

open 2 access

\begin{abstract}
Branched chain amino acids (BCAA) - leucine, isoleucine and valine are essential amino acids which are metabolized directly in muscles and offer energy fuel to performance of the work. There is lot of evidences supporting the positive effect of BCAA supplementation on muscle growth. The main importance is attached particularly to leucine. There was observed that leucine supplementation increased protein synthesis in skeletal muscles after resistance exercise in young people and in elderly people suffered by sarcopenia as well. There is not exactly clear, what is the reason for the positive effect of BCAA to increase protein synthesis in muscles. Besides the positive effect of BCAA on muscle growth, there was observed their positive effect against fatigue and on a production of endogenous glucose, which is necessary to maintain the glucose balance in body during adaptation to stress. The minimum and maximum dose of BCAA is not established, but the daily recommended amount of leucine : isoleucine : valine is in a ratio 40:20:20 mg.kg body weight ${ }^{-1}$. It is recommended to use the mixture of BCAA rather than leucine individual, because of depletion other BCAA in body. There was observed no toxicity of BCAA even at high doses. The present review describes the metabolism of action and effect of BCAA on protein synthesis and physiological functions in human.
\end{abstract}

Keywords: Branched chain amino acid; protein; leucine; isoleucine; valine

\section{INTRODUCTION}

Well balanced amino acids content of protein diet is necessary for lean muscle growth. Required amount of dietary protein is necessary for protein synthesis. Not only proteins but also amino acids, constituents that make up proteins, are important part of nutrition which could not be neglected, especially when resistance exercise is performed. Besides the supplementation of complex essential amino acids, that the body is not able to synthesize, supplementation of branched chain amino acids (BCAA) is important. Leucine, isoleucine and valine are of the same structure of branched chain and so they are known as branched chain amino acids - BCAA. They belong among essential amino acids for humans and animals and have common membrane transport systems and enzymes for their transamination and decarboxylation (Harper et al., 1984). It indicates that they are closely connected with their metabolism in a body. BCCA represent $35-40 \%$ of dietary essential amino acids in body proteins and 14-18 $\%$ of total amino acids present in muscle proteins (Riazi et al., 2003; Layman and Baum, 2004).

Table 1 Content of BCAA in different foods, feeds and protein sources $\left(\mathrm{g} \cdot \mathrm{kg}^{-1} \mathrm{DM}\right) *$

\begin{tabular}{lcccccc}
\hline \hline & CP & Leu & Ile & Val & $\begin{array}{c}\text { Total } \\
\text { BCAA }\end{array}$ & $\begin{array}{c}\text { BCAA expressed as \% } \\
\text { of CP }\end{array}$ \\
\hline \hline & & & & & & \\
Leu : Ile : Val
\end{tabular}

* BCAA - branched chain amino acids; $\mathrm{CP}$ - crude protein; Leu -leucine; Ile - isoleucine; Val - valine

${ }^{1}$ Brestenský et al., (2013), ${ }^{2}$ NRC (2012), ${ }^{3}$ Gottlob et al., (2012) 
Human musculature represents $40 \%$ of total body weight of a man, and so muscle proteins "pool" represents very large reservoir of BCAA in the body. But the content of free BCAA in skeletal muscle of human is low; only $0.1 \mathrm{~g}(0.6-1.2$ $\mathrm{mmol})$ /muscle $\mathrm{kg}$ (Rennie, 1996). Total concentration of BCAA in human blood (0.3-0.4 mmol/l) is relatively high when compared with other amino acids (except for glutamine) (Ahlborg et al., 1974; Wahren et al., 1976). However, in comparison with content of BCAA in muscle, total amount of BCAA in human blood is low.

Content of individual and total BCAA among various feeds and protein sources is different (Table 1). The higher content is in protein sources compared to foods and feeds. Leucine content is between $41-58 \%$ of total BCAA and the ratio of leucine : isoleucine : valine is similar within the foods and protein sources as well, but is not completely identical to recommended ratio 2:1:1 (Kurpad et al., 2006), and is slightly higher, regarding isoleucine and valine. The content of BCAA corresponds to the content of crude protein (Fig. 1)

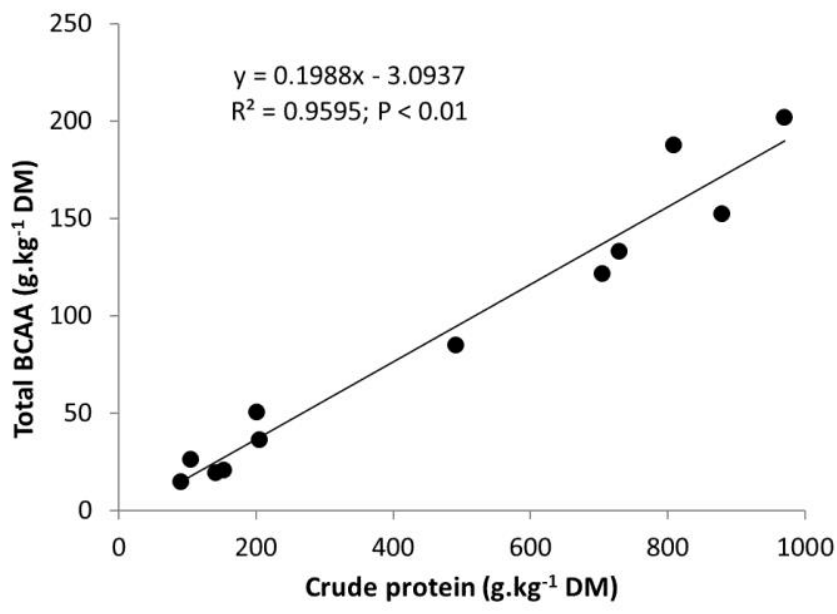

Figure 1 The ratio of total content BCAA to crude protein in foods, feeds and protein sources

\section{BCAA metabolism in the body}

In contrast to other amino acids, BCAA are metabolized directly in the muscles and their catabolic pathways are located in the mitochondria. The first step in BCAA metabolism in tissues is production of branched chain keto acids that are incorporated into proteins or circulate in the body and serve as an energy substrate for skeletal muscle, brain, liver and heart (Abumrad et al., 2001) Branched chain amino acid aminotransferase (BCAT) enzyme is responsible for change of BCAA into keto acids. Another enzyme - branched-chain $\alpha$-keto acid dehydrogenase (BCKDH) causes decarboxylation of keto acids in the tissues and organs with generation of substrates entering the citrate cycle (Darner and Elsas, 1989). BCAA catabolism is carried out in two steps (Fig. 2): 1) reversible transamination of $\alpha$-keto acids in presence of BCAT (Bixel et al., 1997); 2); the second step is catalyzed by BCKDH and it is irreversible (Harris et al., 1997). Alpha-keto acids generated during this step are subject to oxidative decarboxylation from which derivatives of coenzyme A are generated (Platell $\boldsymbol{e}$ al., 2000). Intensity of BCAA oxidation is different in individual tissues and it depends on the activity of transaminase and dehydrogenase. BCKDH exists both in active form (dephosphorylated) and in non-active form (phosphorylated) Enzyme that is responsible for activation and inactivation of $\mathrm{BCKDH}$ is BCKDH-kinase which occurs particularly in mitochondria (Anderson and Hanson, 1983; Harris et al., 1997). BCKDH is activated during training by dephosphorylation of BCKDH-kinase. It was found that activity of BCKDH in the muscles is increased 10-times during training (Kasperek et al., 1985) Increased activity of $\mathrm{BCKDH}$ was also observed during starvation (Kasparek, 1989). Dephosphorylation is connected with decrease of ATP level in the muscles (Shimomura et al., 1995). BCAT concentrations are the highest in the skeletal muscle, and so muscles are the main place of BCAA transamination (Harper et al., 1984). During increased physical activity or during the stress and infection periods (when there is increased consumption and lack of energy in the body), BCAA metabolism in the skeletal muscle is increased. When catabolism of proteins is increased, flow of BCAA is also increased.

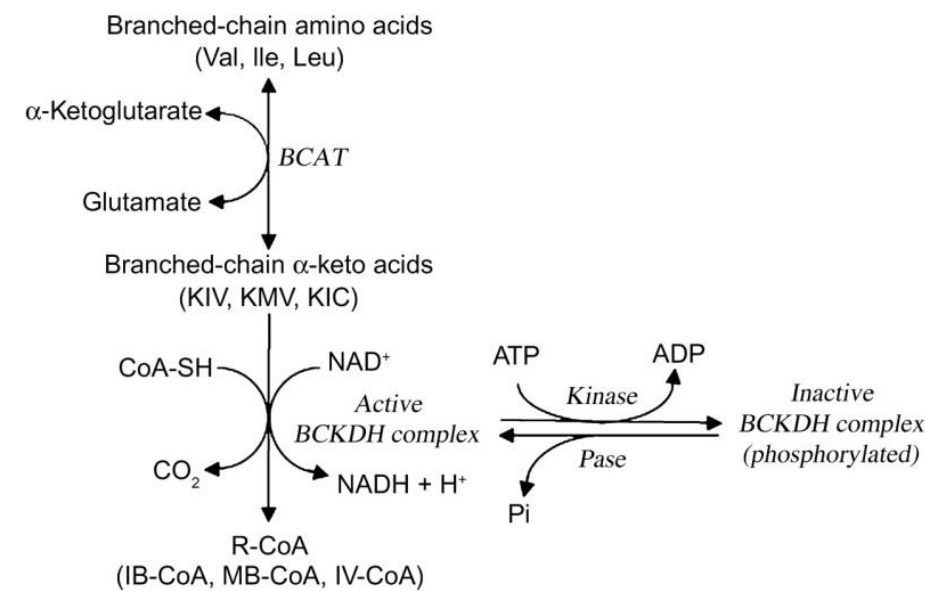

B-CoA, MB-CoA, IV-CoA

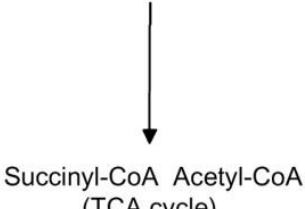

(TCA cycle)

Figure 2 Degradation pathway for branched-chain amino acids (BCAA); BCAT: branched-chain amino acid transaminase; BCKDH: branched-chain $\alpha$-keto acid dehydrogenase; KIV: $\alpha$-ketoisovalerate; KMV: $\alpha$ - keto-beta-mehylvalerate; KIC: $\alpha$-ketoisocaproate; CoA-SH: coenzyme A reduced form; IV-CoA: isovaleryl CoA; R-CoA: acyl CoA; Pase: phosphatase (Shimomura et al., 2004).

\section{Catabolic state of the body and BCAA}

Catabolic state of the body is characterized by increased proteolysis, gluconeogenesis, decreased proteosynthesis and negative nitrogen balance. These states can be observed most often during infections, diseases and nutritional deficiencies. Therefore, it is very important to protect muscle mass during catabolic states, particularly during periods with increased occurrence of infections.

BCAA oxidation is increased during catabolic state of the body. In this time BCAA represent important source of energy for skeletal muscle (Platell $\boldsymbol{e t}$ al. 2000). Changes in BCAA metabolism during catabolic states are influenced by long-term activity of BCKDH (Garcia-Martinez et al., 1985) what explains increased oxidation of BCAA. Several studies reported that administration of BCAA to people in catabolic states (postoperative, multiple trauma, severe burns and sepsis) improved nitrogen balance, increased concentration of amino acids in the plasma, increased protein synthesis and decreased catabolism in the skeleta muscle (Echenique et al., 1984). Based on this information it is evident that BCAA protect muscles when the body is in catabolic state caused by insufficient nutrition or diseases.

\section{Fatigue and brain function}

It is assumed that BCAA concentration in plasma affects brain functions, appetite, as well as physical and mental fatigue. BCAA influence brain functions by changing of utilization of the aromatic amino acids. Leucine, isoleucine and valine directly or indirectly participate on different bio-chemical reactions in the brain (Fernstrom, 1990), such as protein synthesis, energy production, compartmentalization of glutamate, neurotrasmitter serotonin synthesis (Suryawan et al., 1998; Daikhin and Yudkoff, 2000)

BCAA are transferred by blood to the brain via blood brain barrier transport system and they are the main source of nitrogen for production of glutamate and glutamine in the brain (Chuang et al., 1995) and serve as energy substrate for the brain. They are swiftly metabolized in the neurons also despite the fact that there is sufficient amount of other energy substrates, such as glucose. BCAA and particularly leucine provide amino group necessary for glutamate synthesis (Kanamori et al., 1998; Hutson et al., 2001) and they are a source of nitrogen for peripheral tissues in the amount of 30-50\% (Yudkoff et al., 2005). Leucine crosses rapidly into the brain, first passing into astrocytes, where it is swiftly transaminated. Glutamate and branched chain keto acids are products of transamination, and keto isocapronate (KIC) is a product of leucine (Fig. 2) Glutamate is neurotransmitter which acts as a stimulator that increases neuron activity in the brain. The brain can oxidize KIC and leucine to $\mathrm{CO}_{2}$ (Auestad et al., 1991), but degree of this oxidation is lower than the degree of transamination (Shambaugh and Koehler, 1983).

Blood brain barrier transport system is the same for both BCAA and tryptophan. Since this transport system has limited capacity, BCAA and tryptophan compete to transfer also through this transport system. When BCAA concentration in the blood increases, transport of tryptophan to the brain is decreased (Fernstrom 
2005). Due to the fact that tryptophan is metabolized in the brain to 5 hydroxytryptamine (5-HT; serotonin), reduced transfer of tryptophan into the brain will result to reduce the amount of metabolized 5-HT, which has slightly sedative effects and is responsible for fatigue (Struder et al., 1998; Blomstrand, 2006)

Increased BCAA concentrations in the blood suppress fatigue by blocking the entry of tryptophan into the brain. This is also confirmed by several works dealing with effect of BCAA on fatigue. When a mixture of BCAA was administered to people during training, they stated reduction of exertion and mental fatigue (Blomstrand et al., 1997). Similarly, also physical performance measured as a time to exhaustion was improved from 137 minutes to 153 minutes. (Mittleman et al., 1998).

\section{BCAA and glucose metabolism}

Due to increased degradation of BCAA in peripheral tissues, increasing the concentration of BCAA occurs in cells. Decomposition of BCAA in the skeletal muscle results in increased production of alanine and glutamine and maintenance of glucose equilibrium in the body (Layman 2003). The relationship between BCAA and the glucose level is related to glucose-alanine cycle (Ahlborg $\boldsymbol{e t}$ al 1974), within which BCAA are released from the liver. Subsequently, released BCAA are transmitted by blood to the muscles. Uptake of BCAA in the skeletal muscles increases concentration and transamination of BCAA in the cells and incorporation of amino nitrogen into pyruvate from which alanine is produced. Alanine is transmitted from the muscles to the liver by blood, where it is changed to pyruvate from which glucose is produced. Amino acids serve as a primary source of carbon necessary for gluconeogenesis (Jungas et al., 1992). Production of endogenous glucose is a crucial factor for maintaining the balance of glucose in the body (Balasubramanyam et al., 1999). BCAA provide $25-30 \%$ of nitrogen necessary for formation of alanine (Haymond $\boldsymbol{e t}$ al., 1978), from which glucose is produced. Glucose is important in the process of adaptation to stress and starvation.

\section{BCAA and protein metabolism}

Recent studies showed that free BCAA, particularly leucine, play important role in protein metabolism. Leucine stimulates protein synthesis and prevents breakdown of proteins by a mechanism containing so called mammalian target of rapamycin - mTOR (serine - threonine - protein kinase regulating growth proliferation, motility, and survival of cells and synthesis and transcription of proteins) (Mordier et al., 2000; Bolster et al., 2004). Leucine is not only a structural part of proteins, but it also forms protein metabolism. BCAA are metabolized out of liver in the skeletal muscle (Buse and Reid, 1975; Shinnick and Harper, 1976). They are important source of energy in the muscles during training and in stress periods, as well as precursors of other amino acids and proteins (Ferrando et al., 1995). The main source of energy for muscles is oxidation of BCAA (Shinnick and Harper, 1976; Harper et al., 1984). The oxidation is controlled by by-products of leucine transamination for short time (Parker and Randle, 1978) and by many physiological and pathological conditions for long time period, such as starvation, diabetes, inflammation processes, cancer illnesses and infections (Harris et al., 1985; Argiles and Lopez-Soriano, 1990; Nawabi et al., 1990; Hayashi et al., 1996; Lombardo et al., 1998; Price et al., 1998).

Moreover, BCAA significantly affect glutamine metabolism (Darmaun and Dechelotte, 1991). Glutamine is important nutrient for rapidly growing cells in the body, particularly in intestine and immune system. BCAA are transferred from food through the liver to the system circulation of the body, where more than $60 \%$ of them are processed by metabolism in the muscles (Gelfand $\boldsymbol{e t}$ al., 1986). They are used as oxidative source of energy in the muscles. They stimulate glutamine and alanine synthesis, which are exported to the liver. Here they form glucose that is a source of energy. There is so called liver-muscle metabolic pathway in the body. This pathway is particularly important during starvation, because alanine, which is synthesized in the muscles de novo, becomes a main precursor for the liver gluconeogenesis. Alanine carbon is mostly created by BCAA, particularly by valine (Freund $\boldsymbol{e t}$ al., 1979).

Increased availability of amino acids and resistance training directly increase synthesis of proteins in the skeleton musculature. BCAA, particularly leucine, have anabolic effect on protein metabolism in such a way that they increase degree of protein synthesis and decrease degree of proteolysis in the skeletal musculature of people staying in rest (Louard et al., 1990; Nair et al., 1992). BCAA have anabolic effect in the skeletal muscle also during recovery period after the training (Blomstrand and Saltin, 2001). The administration of BCAA increases phosphorylation of proteins that participate on regulation of protein synthesis, including p70S6K in human skeletal musculature (Liu et al., 2001) The p70S6k a serine threonine kinase is an enzyme, which goal is S6 ribosome protein. Its phosphorylation indicates protein synthesis in ribosome. The p70S6k activity induced by training correlates with growth of skeletal musculature observed after six weeks of resistance training and with increased degree of protein synthesis (Baar and Esser, 1999). Changes in p70S6k phosphorylation in skeletal musculature after the training can reflect activation of so called signal pathways that can be responsible for growth of protein synthesis during early recovery period after the training. It is assumed that BCAA increase protein synthesis in the skeletal musculature during recovery after resistance training by p70S6k signaling cascade (Karlsson et al., 2004).

Resistance training increases musculature due to higher degree of protein synthesis compared to protein breakdown, but the net protein increase was achieved only in combination with a nutritional supplement (Biolo et al., 1997; Tipton et al., 1999). Synthesis of myofibril proteins increases, and because these proteins form $80 \%$ of skeletal proteins, the effect of resistance training can be measured as an increase of muscles volume or a cross-section of muscle fiber after the training (Tesch, 1988).

\section{Importance of leucine for protein synthesis}

Studies carried out with people in rest showed that the BCAA administration, particularly leucine, has anabolic effect on protein metabolism what is reflected either with increased protein synthesis or decreased protein breakdown (Alvestrand et al., 1990; Louard et al., 1990; Nair et al., 1992). In spite of the fact that relatively quick response on increase of efficiency of amino acids in the body was observed, time necessary for stimulation effect of the amino acids on protein metabolism is not known (Bohé et al., 2001). The BCAA mixture infusion stimulated the protein synthesis for 30 minutes after the infusion and it also increased the degree of synthesis for another 90 minutes (Bohé et al., 2001). The infusion of BCAA or pure leucine increased phosphorylation of p70S6k kinase and 4E-BP1 in the skeletal musculature for 2 to 6 hours (Greiwe $\boldsymbol{e t}$ al. 2001; Liu et al., 2001). Increase of phosphorylation of p70S6k kinase was confirmed 6 hours after taking the infusion consisting of amino acids mixture. In relation to resistance training, intake of amino acids or protein hydrolyzate after the training stimulates the degree of protein synthesis in the muscles and causes positive nitrogen balance (degree of protein synthesis is higher than degree of protein breakdown) (Rasmussen et al., 2000; Børsheim et al., 2002; Tipton et al., 2004). There are different theories explaining this effect: 1) Increased efficiency of amino acids increases their transport to the muscles. It is assumed that it stimulates degree of protein synthesis in the muscles (Wolfe, 2001), 2) Another possibility is that the stimulation effect of one amino acid or a group of several amino acids occurs, e.g. BCAA - particularly leucine. High concentrations of leucine are related to protein synthesis of proteins (Ferrando $e t$ al., 1995; Louard et al., 1995). Approximately $40 \%$ of leucine transported to muscles passes to amino acids pool, $40 \%$ is oxidized and $20 \%$ of leucine becomes part of proteins (Alvestrand $\boldsymbol{e t}$ al., 1990). An addition of leucine to protein hydrolyzate leads to higher stimulation of protein synthesis after the resistance training, in comparison if only hydrolyzate without addition of leucine is used (Koopman et al., 2005). It is documented that leucine causes release of insulin from the pancreas and it is assumed that the anabolic effect of leucine is connected with insulin. When BCAA had been administered during endurance training (running, cycling), their positive effect was observed during the recovery period, as well as during the training (Blomstrand and Newsholme, 1992; Blomstrand and Saltin, 2001)

Moreover, leucine as the main regulator of protein synthesis in the muscles plays an important role in reduction of sarcopenia - loss of muscle mass associated with aging. With aging, the muscles do not response to anabolic effect of amino acids (Cuthbertson et al., 2005) and antiproteolytic effect of insulin (Wilkes $\boldsymbol{e t}$ al., 2009) and the degree of protein synthesis in muscles is decreased. Studies carried out on rats (Rieu et al., 2003) and men (Kastanos et al., 2006; Rieu et al., 2006) showed that leucine is able to restore the degree of protein synthesis in old muscles. In case of consumption of essential amino acids in the amount of 6.7 $\mathrm{g}$ (of which $26 \%$ is leucine) the degree of protein synthesis in the muscles of elderly people was not increased; it was increased only in the muscles of young people. But after increasing the content of leucine to $41 \%$, the degree of protein synthesis in the muscles was equally increased both in case of young and old people (Katsanos et al., 2006). This effect was not observed, when the leucine was consumed together with common meal. When the leucine is administered separately in the form of a dietary supplement, a level of other BCAA in plasma can be depleted (Dardevet et al., 2000). Therefore, more efficient and suitable is to use balanced mixtures of BCAA than free leucine (Balage and Dardevet, 2010). Supplementation by leucine is more effective, when it is combined with resistance training, because synthesis of myofibril proteins is stimulated after the training. Beside this fact, both forms - either training or nutrition are effective strategies for increasing of muscle mass of elderly people (Churchward-Venne et al., 2012). There is not well established daily recommended dose of BCAA but only mutual ratio of leucine : isoleucine : valine, in proportion of $2: 1: 1$. Some studies recommended dose of leucine : isoleucine : valine in a daily amount of 40: 17-20 : 20 mg.kg body weight ${ }^{-1}$ (Kurpad et al., 2006), but some studies reported beneficial effect of BCAA at minimum dose in a daily amount higher than $5 \mathrm{~g}$ (Shimomura et al., 2004). Despite this fact, EFSA (2012) reported that there is no evidence that leucine supplementation in daily dose higher than 39 mg.kg body weight ${ }^{-1}$, would be effective in promoting of muscle growth Supplementation of BCAA is safe. In animal studies, there was demonstrated no toxicity even at doses exceeding 10 g.kg body weight ${ }^{-1}$ (Okazaki et al., 1989). 


\section{CONCLUSION}

It was well documented the positive effect of BCAA supplementation to the diet on protein synthesis. Especially when resistance training is performed, in order to stimulate muscle growth, BCAA play important role as an energy fuel and constituent stimulating protein synthesis. More over BCAA have positive effect against sarcopenia in elderly people. Based on this information, BCAA supplements are important part of protein nutrition but minimal dose for their beneficial effect is not clearly established. In conclusion, it is necessary to note that to achieve positive effect of BCAA on muscle mass formation of people taking BCAA mixtures, these people should also take sufficient amount of other, particularly essential amino acids, especially in the form of different proteins directly from meal or in the form of dietary supplements.

Acknowledgments: This article was written during realization of the project "ZDRAVIE no. 26220220176" supported by the Operational Programme Research and Development funded from the European Regional Development Fund.

\section{REFERENCES}

ABUMRAD, N., ROBINSON, R., GOOCH, B., LACY, W. 1982. The effect of leucine infusion on substrate flux across the human forearm. Journal of Surgical Research, 32(5), 453-463.

AHLBORG, G., FELIG, P., HAGENFELDT, L., HENDLER, R., WAHREN, J. 1974. Substrate turnover during prolonged exercise in man. Journal of Clinical Investigation, 53(4), 1080- 1090. http://dx.doi.org/10.1172/JCI107645

ALVESTRAND, A., HAGENFELDT. L., MERLI K, OURESHI A, ERIKSSON LS. 1990. Influence of leucine infusion on intracellular amino acids in humans European Journal of Clinical Investigation, 20(3), 293-298. http://dx.doi.org/10.1111/j.1365-2362.1990.tb01858.x

ANDERSON, N. G., HANSON, P. J. 1983. Arteriovenous differences for amino acids across control and acid-secreting rat stomach in vivo. Biochemical Journal, 210(2), 451-455.

ARGILES, J. M., LOPEZ-SORIANO, F. J. 1990. The oxidation of leucine in tumour-bearing rats. Biochemical Journal, 268(1), 241-4.

AUESTAD, N., KORSAK, R. A., MORROW, J. W., EDMOND, J. 1991. Fatty acid oxidation and ketogenesis by astrocytes in primary culture. Journal of Neurochemistry, 56(4), 1376-1386. http://dx.doi.org/10.1111/j.1471 4159.1991.tb11435.x

BAAR, K., ESSER, K. 1999. Phosphorylation of p70S6k correlates with increased skeletal muscle mass following resistance exercise. American Journal of Physiology Cell Physiology, 276(1), C120-C127. PMid: 9886927

BALAGE, M., DARDEVET, D. 2012. Long-term effects of leucine supplementation on body composition. Current Opinion in Clinical Nutrition and Metabolic Care, 13(3), 265-270. http://dx.doi.org/10.1097/MCO.0b013e328336f6b8

BALASUBRAMANYAM, A., MCKAY, S., NADKARNI, P., RAJAN, A. S., FARZA, A., PAVLIK, V., HERD, J. A., JAHOOR, F., REEDS, P. J. 1999 Ethnicity affects the postprandial regulation of glycogenolysis. American Journal of Physiology - Endocrinology and Metabolism, 40(5Pt1): E905-E914.

BIOLO, G., TIPTON, K. D., KLEIN, S., WOLFE, R. R. 1997. An abundant supply of amino acids enhances the metabolic effects of exercise on muscle protein. American Journal of Physiology, 273(1Pt), E122-E129. PMid:9252488 BIXEL, M. G., HUTSON, S. M., HAMPRECHT, B. 1997. Cellular distribution of branched-chain amino acid aminotransferase isoenzymes among rat brain glia cells in culture. Journal of Histochemistry and Cytochemistry, 45(5), 685-694. http://dx.doi.org/10.1177/002215549704500506

BLOMSTRAND, E. 2006. A Role for Branched-Chain Amino Acids in Reducing Central Fatigue. Journal of Nutrition, 136(2), 544S-547S

BLOMSTRAND, E., HASSMEN, P., EK. S., EKBLOM, B., NEWSHOLME, E. A. 1997. Influence of ingesting a solution of branched-chain amino acids on perceived exertion during exercise. Acta Physiologica Scandinavica, 159(4), 41 49. http://dx.doi.org/10.1046/j.1365-201X.1997.547327000.x

BLOMSTRAND, E., NEWSHOLME, E. A. 1992. Effect of branched-chain amino acid supplementation on the exercise-induced change in aromatic amino acid concentration in human muscle. Acta Physiologica Scandinavica, 146(3), 293-298. PMid:1481685

BLOMSTRAND, E., SALTIN, B. 1999. Effect of muscle glycogen on glucose lactate and amino acid metabolism during exercise and recovery in human subjects. Journal of Physiology, 514(Pt1), 293-302. http://dx.doi.org/10.1111/j.1469-7793.1999.293af.x

BLOMSTRAND, E., SALTIN, B. 2001. BCAA intake affects protein metabolism in muscle after but not during exercise in humans. American Journa of Physiology - Endocrinology and Metabolism, 281(2), E365-E374. PMid:11440914

BOHÉ, J., LOW, A., WOLFE, R. R., RENNIE, M. J. 2003. Human muscle protein synthesis is modulated by extracellular, not intramuscular amino acid availability: a dose-response study. Journal of Physiology, 552(1):315-324 PMid:12909668
BOHÉ, J., LOW, J. F. A., WOLFE, R. R., RENNIE, M. J. 2001. Latency and duration of stimulation of human muscle protein synthesis during continuous infusion of amino acids. Journal of Physiology, 532(2), 575-579. http://dx.doi.org/10.1111/j.1469-7793.2001.0575f.x

BOLSTER, D. R., JEFFERSON, L. S., KIMBALL, S. R. 2004. Regulation of protein synthesis associated with skeletal muscle hypertrophy by insulin-, amino acid- and exercise induced signaling. Proceedings of the Nutrition Society, 63(2), 351-356. PMid:15294054

BOOTH, F. W., TSENG, B. S., FLUCK, M., CARSON, J. A. 1998. Molecular and cellular adaptation of muscle in response to physical training. Acta Physiologica Scandinavica, 162(3), 343-350. PMid: 9578380

BØRSHEIM, E, TIPTON, K. D., WOLF, S. E., WOLFE, R. R. 2002. Essential amino acids and muscle protein recovery from resistance exercise. American Journal of Physiology - Endocrinology and Metabolism, 283(4), E648-E657. PMid:12217881

BRAND, K. 1981. Metabolism of 2-oxoacid analogues of leucine, valine and phenylalanine by heart muscle, brain and kidney of the rat. Biochimica et Biophysica Acta, 677(1), 126-132.

BRESTENSKÝ, M., NITRAYOVÁ, S., PATRÁŠ, P., HEGER, J., 2013. Standardized ileal digestibilities of amino acids and nitrogen in rye, barley, soybean meal, malt sprouts, sorghum, wheat germ and broken rice fed to growing pigs. Animal feed Science and Technology, 186(1-2), 120- 124 http://dx.doi.org/10.1016/j.anifeedsci.2013.09.006

BUSE, M. G., REID, S. S. 1975. Leucine -A possible regulator of protein turnover in muscle. Journal of Clinical Investigation, 56(5), 1250-1261. http://dx.doi.org/10.1172/JCI108201

CARRARO, F., STUART, C. A., HARTL, W. H., ROSENBLATT, J., WOLFE,

R. R. 1990. Effect of exercise and recovery on muscle protein synthesis in human subjects. American Journal of Physiology, 259(4), E470-E476. PMid:2221048 CUTHBERTSON, D., SMITH, K., BABRAJ, J., LEESE, G., WADDELL, T. ATHERTHON P., WACKERHAGE H. et al., 2005. Anabolic signaling deficits underline amino acid resistance of wasting, ageing muscle. FASEB Journal, 19(3), 422-424. http://dx.doi.org/10.1096/fj.04-2640fje

DAIKHIN, Y., YUDKOFF, M. 2000. Compartmentation of brain glutamate metabolism in neurons and glia. Journal of Nutrition, 130(4), 1026S-1031S.

DARDEVET, D., SORNET, C., BALAGE, M., GRIZARD J. 2000. Stimulation of in vitro rate muscle protein synthesis by leucine decreases with age. Journal of Nutrition, 130(11), 2630-2635. PMid:11053498

DARMAUN, D., DECHELOTTE, P. 1991. Role of leucine as a precursor of glutamine alpha-amino nitrogen in vivo in human. American Journal of Physiology, 260(2), E326-E329. PMid:1996635

DARNER, D., ELSAS, L. 1989 Disorders of branched chain amino acid and branched chain keto acid metabolism. In: Metabolic Basis of Inherited Disease. New York: McGraw- Hill, 678-679.

ECHENIQUE, M. M., BISTRIAN, B. R., MOLDAWER, L. L., PALOMBO, J. D., MILLER. M. M., BLACKBURN, G. L. 1984. Improvement in amino acid use in the critically ill patient with parenteral formulas enriched with branched chain amino acids. Surgery, gynecology and obstetrics, 159(3), 233-241.

EFSA NDA Panel (EFSA Panel on Dietetic Products, Nutrition and Allergies), 2012. Scientific Opinion on Dietary Reference Values for Protein. EFSA Journal, 10(2), 2557. http://dx.doi.org/10.2903/j.efsa.2012.2557

FARRELL, P. A., HERNANDEZ, J. M., FEDELE, M. J., VARY, T. C., KIMBALL, S. R., JEFFERSON, L. S. 2000. Eukaryotic initiation factors and protein synthesis after resistance exercise in rats. Journal of Applied Physiology, 88(3), 1036-1042. PMid:10710401

FERNSTROM, J. D. 1990. Aromatic amino acids and monoamine synthesis in the central nervous system: influence of the diet. Journal of Nutritional Biochemistry, 1(10), 508-517.

FERRANDO, A. A., WIlliams, B. D., STUART, C. A., LANE, H. W. WOLFE, R. R. 1995. Oral branched-chain amino acid decrease whole body proteolysis. Journal of Parenteral and Enteral Nutrition, 19(1), 47-54. PMid:7658600

FREUND, H., HOOVER, H., ATAMINA, S., FISHER, J. 1979. Infusion of the branched chain amino acids in post operative patients. Annals of Surgery, 190(1) 18-23. http://dx.doi.org/10.1097/00000658-197907000-00004

GARCIA-MARTINEZ, C., LLOVERA, M., LOPEZ-SORIANO, F. J., DEL SANTO, B., ARGILES, J. M. 1995. Lipopolysaccharide (LPS) increases the in vivo oxidation of branched-chain amino acids in the rat: A cytokine-mediated effect. Molecular and Cellular Biochemistry, 148(1), 9-15. http://dx.doi.org/10.1007/BF00929497

GAUTSCH, T. A., ANTHONY, J. C., KIMBALL, S. R., PAUL, G. L. LAYMAN, D. K., JEFFERSON, L. S. 1998. Availability of eIF4E regulates skeletal muscle protein synthesis during recovery from exercise. American Journal of Physiology, 274(2), C406-C414. PMid:9486130

GELFAND, R. A., GLICKMAN, M. G., JACOB, R., SHERWIN, R. S., DEFRONZO, R. A.1986. Removal of infused amino acids by splanchnic and leg tissue in humans. American Journal of Physiology, 250(4), E407-E413. PMid:3963181

GOTTLOB, R. O., DE ROUCHEY, J. M., TOKACH, M. D., GODOMAN, R D., DRITZ, S. S., NELSSEN, J. L., HASTAD, C. W., KNABE, D. A., 2006. 
Amino acid and energy digestibility of protein sources for growing pigs. Journal of Animal Science, 84(6), 1396-1402. http://dx.doi.org/2006.8461396x

GREIWE, J. S., KWON, G., Mc DANIEL, M. L., SEMENKOVICH, C. F. 2001. Leucine and insulin activate p70S6 kinase through different pathways in human skeletal muscle. American Journal of Physiology - Endocrinology and Metabolism, 281(3), E466-E471. PMid:11500301

HARGREAVES, M. 2003. Diet, genes and exercise performance. Asia Pacific Journal of Clinical Nutrition, 12(Suppl), S1.

HARPER, A. E., MILLER, R. H., BLOCK, K. P. 1984. Branched-chain amino acid metabolism. Annual Review of Nutrition, 4, 409-454. http://dx.doi.org/10.1146/annurev.nu.04.070184.002205

HARRIS, R. A., HAWES, J. W., POPOV, K. M., ZHAO, Y., SHIMOMURA, Y., SATO, J., JASKIEWICZ, J., HURLEY, T. D. 1997 Studies on the regulation of the mitochondrial alpha-ketoacid dehydrogenase complexes and their kinases Advances in Enzyme Regulation, 37: 271-293. http://dx.doi.org/10.1016/S0065 2571(96)00009-X

HARRIS, R. A., POWELL, S. M., PAXTON, R., GILlIM, S. E., NAGAE, H. 1985. Physiological covalent regulation of rat liver branched-chain alphaketoacid dehydrogenase. Archives of Biochemistry and Biophysics, 243(2), 542 555. PMid: 4083900

HAYASHI, N., YOSHIHARA, D., KASHIWABARA, N., TAKESHITA, Y., HANDA, H., YAMAKAWA, M. 1996. Effect of carnitine on decrease of branched chain amino acids and glutamine in serum of septic rats. Biological and Pharmaceutical Bulletin, 19(1), 157-159. PMid:8820932

HAYMOND, M. W., BEN-GALIM, E., STROBEL, K. E. 1978. Glucose an alanine metabolism in children with maple syrup urine disease. Journal of Clinical Investigation, 78(2), 398-405. http://dx.doi.org/10.1172/JCI109141

HEDLEY, A. A., OGDEN, C. L., JOHNSON, C. L., CARROLL, M. D. CURTIN, L. R., FLEGAL, K. M. 2004. Prevalence of overweight and obesity among US children, adolescents, and adults, 1999-2002. Journal of the American Medical Association, $291(23), \quad 2847-\quad 2850$ http://dx.doi.org/10.1001/jama.291.23.2847

HENRIKSSON, J. 1977. Training induced adaptation of skeletal muscle and metabolism during submaximal exercise. Journal of Physiology, 270(3), 661675. http://dx.doi.org/10.1113/jphysiol.1977.sp011974

HUTSON, S. M., LIETH, E., LANOUE, K. F. 2001. Function of leucine in excitatory neurotransmitter Metabolism in the central nervous system. Journal of Nutrition, 131(3), 846S-850S

CHESLEY, A., MACDOUGALL, J. D., TARNOPOLSKY, M. A., ATKINSON, S. A., SMITH, K. 1992. Changes in human muscle protein synthesis after resistance exercise. Journal of Applied Physiology, 73(4), 1383-1388 PMid:1280254

CHURCHWARD-VENNE, T. A., WEST, D. W. D., PHILLIPS, S. M. 2012 Amino Acid Supplements and Muscular Performance. In: Amino Acids in Human Nutrition and Health, ed. D'Mello, J. P. F. pp. 291-311. CABI, ISBN-13: 978 845937980.

JUNGAS, R. L., HALPERIN, M. L., BROSNAN, J. T. 1992. Quantitative analysis of amino acid oxidation and related gluconeogenesis in humans. Physiological Reviews, 72(2), 419-448.

KANAMORI, K., ROSS, B. D., KONDRAT, R. W. 1998. Rate of glutamate synthesis from leucine in rat brain measured in vivo by $15 \mathrm{~N}$ NMR. Journal of Neurochemistry, 70(3), 1304-1315. http://dx.doi.org/10.1046/j.14714159.1998.70031304.x

KARLSSON, H. K., NILSSON, P. A., NILSSON, J., CHIBALIN, A. V., ZIERATH, J. R., BLOMSTRAND, E. 2004. Branched-chain amino acid increase p70S6k phosphorylation in human skeletal muscle after resistance exercise. American Journal of Physiology - Endocrinology and Metabolism, 287(1), E1-E7. http://dx.doi.org/10.1152/ajpendo.00430.2003

KASPAREK, G. 1989. Regulation of branched chain 2-oxo acid dehydrogenase activity during exercise. American Journal of Physiology, 256(1Pt1), E186E190

KASPEREK, G. J., DOHM, G. L., SNIDER, R. D. 1985. Activation of branchedchain keto acid dehydrogenase by exercise. American Journal of Physiology, 248(2) (Part 2), R166-R171.

KASTANOS, C. S., KOBAYASHI, H., SHEFFIELD-MOORE, M. AARSLAND, A., WOLFE, R. R. 2006. A high proportion of leucine is required for optimal stimulation of the rate of muscle protein synthesis by essential amino acids in the elderly. American Journal of Physiology - Endocrinology and Metabolism, 291(2), E381-E387. http://dx.doi.org/10.1152/ajpendo.00488.2005 KOOPMAN, R., WAGENMAKERS, A. J., MANDERS, R. J., ZORENC, A. H. SENDEN, J. M., GORSELINK, M., KEIZER, H. A., VAN LOON, L. J. 2005, Combined ingestion of protein and free leucine with carbohydrate increases postexercise muscle protein synthesis in vivo in male subjects. American Journal of Physiology - Endocrinology and Metabolism, 288(4), E645-E653. http://dx.doi.org/10.1152/aipendo.00413.2004

KURPAD, A. V., REGAN, M. M., RAJ, T., GNANOU, J. V. 2006. BranchedChain Amino Acid Requirements in Healthy Adult Human Subjects. Journal of Nutrition, 136(1), 2565 - 2635. PMid:16365094

LAYMAN, D. K. 2003. The Role of Leucine in Weight Loss Diets and Glucose Homeostasis. Journal of Nutrition, 133(1), 261S-267S
LEMON, P. W., MULLIN, J. P. 1980. Effect of initial muscle glycogen levels on protein catabolism during exercise. Journal of Applied Physiology, 48(4), 624629. PMid.7380688

LIU, Z., JAHN, L. A., LONG, W., FRYBURG, D. A., WEI, L., BARRETT, E. J. 2001. Branched-chain amino acids activate messenger ribonucleic acid translation regulatory proteins in human skeletal muscle, and glucocorticoids blunt this action. Journal of Clinical Endocrinology and Metabolism, 86(5), 2136-2143. http://dx.doi.org/10.1210/jcem.86.5.7481

LOMBARDO, Y. B., THAMOTHARAN, M., BAWANI, S. Z., PAUL, H. S., ADIBI, S. A. 1998. Posttranscriptional alterations in protein masses of hepatic branched-chain keto acid dehydrogenase and its associated kinase in diabetes. Proceedings of the Association of American Physicians, 110(1), 40-49. PMid:9460082

LOUARD, R. J., BARRETT, E. J., GELFAND, R. A. 1990. Effect of infused branched chain amino acids on muscle and whole-body amino acid metabolism in man. Clinical Science, 79(5), 457-466. PMid:2174312

LOUARD, R. J., BARRETT, E. J., GELFAND, R. A., 1995. Overnight branched -chain amino acid infusion causes sustained suppression of muscle proteolysis Metabolism - Clinical and Experimental, 44(4), 424-429. http://dx.doi.org/10.1016/0026-0495(95)90047-0

MacDOUGALL, J. D., GIBALA, M. J., TARNOPOLSKY, M. A., MacDONALD, J. R., INTERISANO, S. A., YARASHESKI, K. E. 1995. The time course for elevated muscle protein synthesis following heavy resistance exercise. Canadian Journal of Applied Physiology, 20(4), 480-486 http://dx.doi.org/10.1139/h95-038

MITTLEMAN, K. D., RICCI, M. R., BAILEY, S. P. 1998. Branched-chain amino acids prolong exercise during heat stress in men and women. Medicine and Science in Sports and Exercise, 30(1), 83-91. http://dx.doi.org/10.1097/00005768-199801000-00012

MORDIER, S., DEVAL, C., BECHET, D., TASSA, A., FERRARA, M. 2000. Leucine limitation induces autophagy and activation of lysosome-dependent proteolysis in $\mathrm{C} 2 \mathrm{C} 12$ myotubes through a mammalian target of rapamycinindependent signaling pathway. Journal of Biological Chemistry, 275(38), 29900-29906. http://dx.doi.org/10.1074/jbc.M003633200

NAIR, K. S., SCHWARTZ, R. G., WELLE, S. 1992. Leucine as a regulator of whole body and skeletal muscle protein metabolism in humans. American Journal of Physiology - Endocrinology and Metabolism 263(5), E928-E934. PMid:1443126

NAWABI, M. D., BLOCK, K. P., CHAKRABARTI, M. C., BUSE, M. G. 1990. Administration of endotoxin, tumor necrosis factor, or interleukin 1 to rat activates skeletal muscle branched-chain alpha-keto acid dehydrogenase. Journa of Clinical Investigation, 85(1), 256-263. http://dx.doi.org/10.1172/JCI114421

NRC, 2012. Nutrient Requirements of Swine, 11th rev. ed. The National Academic Press, Washington, DC, USA

OKAZAKI, S., HATAKEYAMA, K., TAMURA, K., TSUFUHISA, S , SHIOTANI, S. 1989. Acute and subacute toxicity study of BCAA-G in rats (in Japanese). Clinical Reports, 23, 1843-1862.

PARKER, P. J., RANDLE, P. J. 1978. Partial purification and properties of branched chain 2-oxo acid dehydrogenase of ox liver. Biochemistry Journal, 171(3), 751-757. PMCid: PMC1184023

PHILLIPS, S. M., TIPTON, K. D., AARSLAND, A., WOLF, S. E., WOLFE, R. R. 1997. Mixed muscle protein synthesis and breakdown after resistance exercise in humans. American Journal of Physiology, 273(1), E99-107. PMid:9252485 PLATELL, C., KONG S. E., Mc CAULEY, R., HALL, J. C. 2000. Branchedchain amino acids. Journal of Gastroenterology and Hepatology, 15(7), 706-717. http://dx.doi.org/10.1046/j.1440-1746.2000.02205.x

PRICE, S. R., REAICH, D., MARINOVIC, A. C., ENGLAND, B. K., BAILEY, J. L., CABAN, R., MITCH, W. E., MARONI, B. J. 1998. Mechanisms contributing to muscle-wasting in acute uremia: activation of amino acid catabolism. Journal of the American Society of Nephrology, 9(3), 439-443. PMid:9513906

RASMUSSEN, B. B., TIPTON, K. D., MILLER, S. L., WOLF, S. E., WOLFE, R. R. 2000. An oral essential amino acid-carbohydrate supplement enhances muscle protein anabolism after resistance exercise. Journal of Applied Physiology, 88(2), 386-392. PMid:10658002

RIAZI, R., WYKES, L. J., BALL, R. O., PENCHARZ, P. B. 2003. The tota branched-chain amino acid requirement in young healthy adult men determined by indicator amino acid oxidation by use of L-[1-13C]phenylalanine. Journal of Nutrition, 133(5), 1383-1389. PMid:12730426

RIEU, I., BALAGE, M., SORNET, C., GIRAUDET, C., PUJOS, E., GIZARD, J., MOSONI, L. et al., 2006. Leucine supplementation improves muscle protein synthesis in elderly men independently of hyperaminoacidaemia. Journal of Physiology, 575(1), 305-315. http://dx.doi.org/10.1113/jphysiol.2006.110742 RIEU, I., SORNET, C., BAYLE, G., PRUGNAUD, J., PUYET, C., BALAGE, M., PAPET, I., et al. 2003. Leucine supplemented meal feeding for ten days beneficially affects postprandial muscle protein synthesis in old rats. Journal of Nutrition, 133(4), 1198-1205. PMid:12672943

SHAMBAUGH, G. E., KOEHLER, R. A. 1983. Fetal fuels VI. Metabolism of aketoisocaproic acid in fetal rat brain. Metabolism, 32(5), 421-427. 
SHIMOMURA, Y., FUJII, H., SUZUKI, M., MURAKAMI, T., FUJITSUKA, N., NAKAI, N.1995. Branched-chain alpha-keto acid dehydrogenase complex in rat skeletal muscle: regulation of the activity and gene expression by nutrition and physical exercise. Journal of Nutrition, 125(6), S1762-S1765.

SHIMOMURA, Y., MURAKAMI, T., NAKAI, N., NAGASAKI, M., HARRIS, R. A. 2004. Exercise promotes BCAA catabolism: effects of BCAA supplementation on skeletal muscle during exercise. Journal of Nutrition, 134(6), $1583 \mathrm{~S}-1587 \mathrm{~S}$

SHINNICK, F. L., HARPER, A. E. 1976. Branched -chain amino acid oxidation by isolated rat tissue preparations. Biochimica et Biophysica Acta, 437(2), 477 486. http://dx.doi.org/10.1016/0304-4165(76)90016-7

SOWERS, J. R. 2003. Obesity as a cardiovascular risk factor. American Journal of $\quad$ Medicine, $115 \quad$ (Supp18A), $37 \mathrm{~S}-41 \mathrm{~S}$. http://dx.doi.org/10.1016/j.amjmed.2003.08.012

STRUDER, H. K., HOLLMANN, W., PLATEN, P., DONIKE, M., GOTZMANN, A., WEBER, K. 1998. Influence of paroxetine, branched-chain amino acids and tyrosine on neuroendocrine system responses and fatigue in humans. Hormone and Metabolic Research, 30(4), 188-194. http://dx.doi.org/10.1055/s-2007-978864

SURYAWAN, A., HAWES, J. W., HARRIS, R. A., SHIMOMURA, Y. JENKINS, A. E., HUTSON, S. M. 1998. A molecular model of human branchedchain amino acid metabolism. American Journal of Clinical Nutrition, 68(1), 72 81.

TESCH, P. A. 1988. Skeletal muscle adaptations consequent to long-term heavy resistance exercise. Medicine and Science in Sports and Exercise, 20(5), S132S134. PMid:3057312

TIPTON, K. D., ELLIOTT, T. A., CREE, M. G., WOLF, S. E., SANFORD, A P., WOLFE, R. R. 2004. Ingestion of casein and whey proteins results in muscle anabolism after resistance exercise. Medicine and Science in Sports and Exercise 36(12), 2073-2081. http://dx.doi.org/10.1249/01.MSS.0000147582.99810.C5

TIPTON, K. D., FERRANDO, A. A., PHILLIPS, S. M., DOYLE, D., WOLFE, R. R. 1999. Postexercise net protein synthesis in human muscle from orally administered amino acids. American Journal of Physiology, 276(4), E628-E634. PMid:10198297

TIPTON, K. D., FERRANDO, A. A., WILLIAMS, B. D., WOLFE, R. R. 1996 Muscle protein metabolism in female swimmers after a combination of resistance and endurance exercise. Journal of Applied Physiology, 81(5), 2034-2038. PMid:8941526

WAHREN, J., FELIG, P., HAGENFELDT, L. 1976. Effect of protein ingestion on splanchnic and leg metabolism in normal man and in patients with diabetes mellitus. Journal of Clinical Investigation, 57(4), 987-999. http://dx.doi.org/10.1172/JCI108375

WILKES, E. A., SELBY, A. L., ATHERTON, P. J., PATEL, R., RANKIN, D., SMITH, K., RENNIE, M. J. 2009. Blunting of insulin inhibition of proteolysis in legs of older subjects may contribute to age-related sarcopenia. American Journal of Clinical Nutrition, $\quad 90(5), \quad 1343-1350$. http://dx.doi.org/10.3945/ajen.2009.27543

WOLFE, R. R. 2001. Effects of amino acid intake on anabolic processes. Canadian Journal of Applied Physiology, 26(S1), S220-S227. http://dx.doi.org/10.1139/h2001-056

YUDKOFF, M., DAIKHIN, Y., NISSIM, I., HORYN, O., LUHOVYY, B., LAZAROW, A., NISSIM, I. 2005. Brain Amino Acid Requirements and Toxicity: The Example of Leucine. Journal of Nutrition, 135(6Suppl):1531S1538 S. 